\title{
COVID-19 PANDEMIC'S IMPACT ON TOURISM IN POLAND IN MARCH 2020
}

\author{
Bartosz KORINTH* \\ University of Gdańsk, Faculty of Oceanography and Geography, Poland, e-mail: bartosz.korinth@wp.pl
}

Ruwan RANASINGHE

Wellassa University, Faculty of Management, Sri Lanka, e-mail: ruwan.fm@gmail.com

Citation: Korinth, B., \& Ranasinghe, R. (2020). COVID-19 PANDEMIC'S IMPACT ON TOURISM IN POLAND IN MARCH 2020. GeoJournal of Tourism and Geosites, 31(3), 987-990. https://doi.org/10.30892/gtg.31308-531

\begin{abstract}
The outbreak of Coronavirus Covid-19 pandemic caused global economic gloom in the first quarter of 2020. This crisis has particularly impacted tourism, which is the subject of this paper. Data regarding air traffic in March 2020 compiled by Polish Air Navigation Services Agency has been put to a detailed analysis. Accommodation occupancy rate in this period was analysed using statistic s presented by STR company. The analyses' conclusion clearly indicates on significant decrease in Poland's tourism in March 2020. Occupancy rate declined in about $40 \%$ in comparison to data from last year, with fall in air traffic on Polish airports (resulting from stopping internat ional air links) in about $80-90 \%$ in comparison to the same period last year.
\end{abstract}

Key words: covid-19, tourism, Poland, air traffic, accomodation occupancy

\section{INTRODUCTION}

Novel Corona (COVID 19) virus first appeared in Wuhan, China in the latter part of 2019. It is a virus of the same category a s SARS, MERS, and it causes respiratory complexities and pneumonia that can lead to death. The origin of the virus is controvatial as at present USA and China accuse each other for producing it. However, the outbreak gradually took place invading Italy, Spain, Iran, South Koria, USA, India, Brasil and almost every country until the end of May 2020. The virus infection is critical and has challenged the medical science to work hastily for a cure for which another several months will be taken as WHO predicts. Thus, the pandemic has become a global challenge claiming novel approaches for global operations, business (Abu Bakar and Rosbi, 2020) and day-to-day behaviors of individuals (Wahyuningtyas et al., 2020). The decrease in the number of tourists may be even greater than in the case of the impact of relatively recent terrorist attacks in tourist regions such as Egypt and Tunisia (Wendt, 2016; 2019a).

COVID 19 or Novel Corona outbreak has taken over almost all countries in the world and influenced the daily lives of billions of people globally. The medical experts confirm that the average number of new infections generated by a single infected person is over five times as compared to the seasonal flu. Thus, Novel Corona outbreak has influenced the normal functioning of an individual, household, village, city, province, country, region and that of entire globe at present. Thus, following the strict measures taken by the Chinese government in closing down Wuhan until the outbreak is controlled, almost all the countries have taken varying measures from restrict movements, continuous curfew, total lockdown, to travel restrictions, suspending air travel operations to control the pandemic (Ranasinghe et al., 2020). The consequences of these measures have begun to emerge immediately in every corner of the world (Ranasinghe, 2020). The severest impact is on daily waged employees who are struggling to meet their hand to mouth existence and millions of employees are at risk of being fired from their employment. Manufacturers, distributors, producers, sellers are struggling to function their organizations, paying salaries, maintaining properties and so forth. The economic loss globally is estimated to be 3-6 trillion USD by the Asian Development Bank (2020). As a result of the coronavirus epidemic, new tourism (Wendt, 2020) takes on a new dimension in the 21st century.

The COVID 19 outbreak has been declared as a global pandemic by WHO and has arrested almost every economy at present in the globe. As combatting measures, many economies are in lockdown condition where consumptions are decreased and productions are seized. The global networks and supply chains are disrupted and functions of organizations from micro to multinational scale are disturbed. Millions of employees are at the danger of losing their jobs as companies will start to lay off staff as controlling measure to respond to the growing conditions. The panic purchasing and storage of FMCGs and food items has created shortage of consumables in many stores around the globe.

COVID 19 was declared a pandemic which will change entire globe due to its outbreak. Ironically, the outbreak is equally influencing both low-income, mid-income and high-income countries and subsequently the entire global networks of business operations. The global economy is at a tremendous challenge as has never been since both demand and supply shocks and routine operations of all economic activities are challenged at the same time. Break down of global financial indices, sinking oil prices, halt of air transportation, seizing global tourism industry, ever low interest rates, disturbances over global supply chains and their spillover effects have significantly challenged neoliberal capitalistic economic operations globally (Ilieș et al., 2018; Wendt, 2018; Ranasinghe and Li, 2020). However, the global recession is invertible and the magnitude of the recession solely depends on the duration of lockdown. The following table summarizes the three scenarios of global lockdown and its impact on economic shrinkage.

COVID-19 started its worldwide spread at the end of 2019. Initially it was present only in China, however within a few days it reached other Asian countries such as South Korea, Thailand and Japan. Infection was spread by people travelling from Chinese city of Wuhan (Carlos et al., 2020) and the pace of its proliferation resulted in WHO's announcement on a critical situation regarding public health (Sohrabi et al., 2020) followed by a notice on an epidemic becoming a pandemic on Wednesday, March 11 (Cascella et al., 2020). Poland's first confirmed Coronavirus infection was announced on March 4, 2020 - a 66 years old man from Lubuskie voivodeship, who returned to Poland from Germany by bus (Serwis Rzeczypospolitej Polskiej - gov.pl from March 4, 2020, accessed: 14.05.2020). Within the following days media informed about other cases - mostly people who had travelled with the first person infected (Koronawirus w Polsce. Minister zdrowia:

\footnotetext{
${ }^{*}$ Corresponding author
} 
Jest kolejny przypadek choroby/ Coronavirus in Poland. Health Secretary: We have another case, Wprost, from March 7, 2020, accessed 14.05.2020). In the following days the number of people infected with COVID-19 started to increase noticeably (Figure 1).

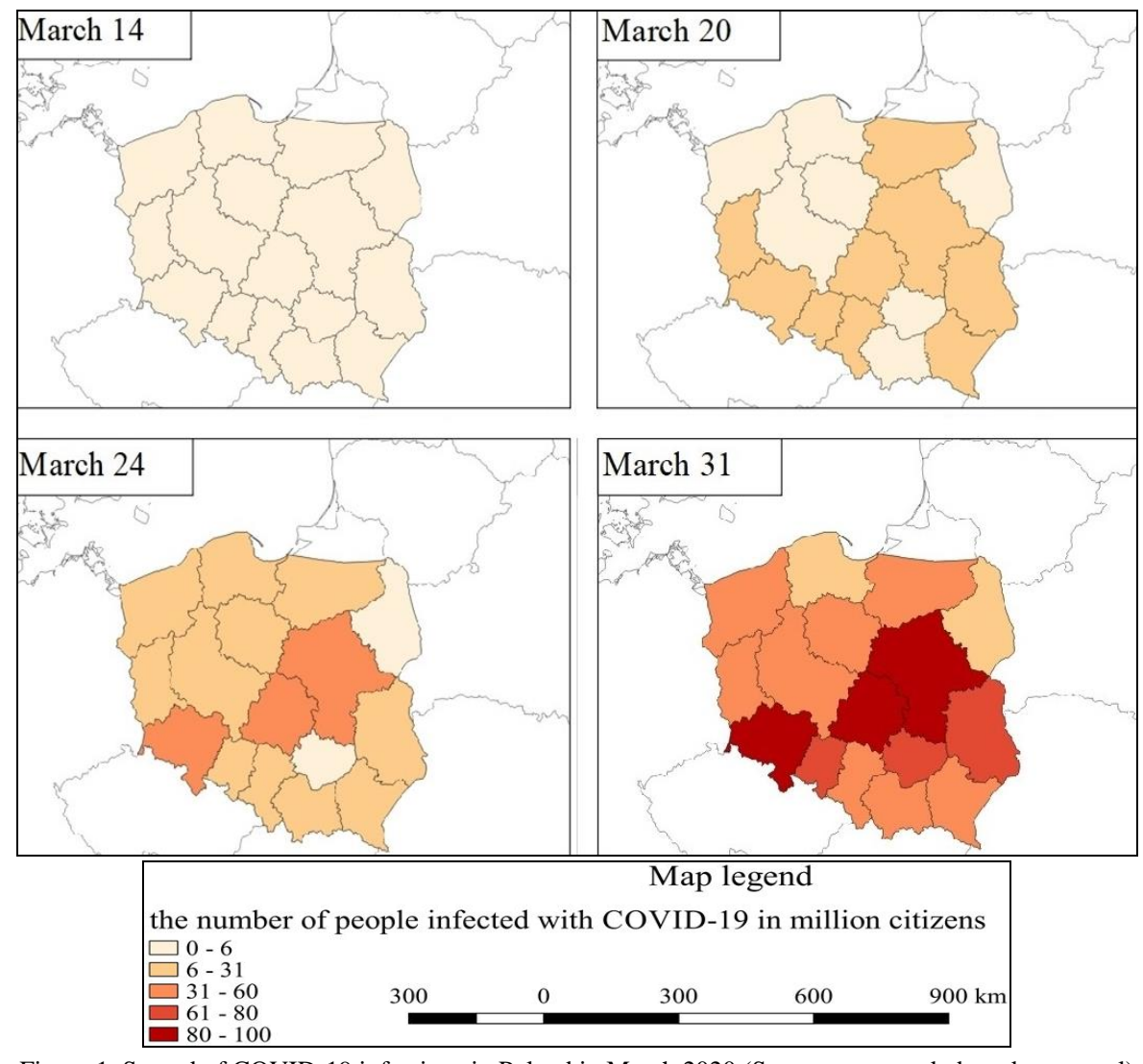

Figure 1. Spread of COVID-19 infections in Poland in March 2020 (Source: own study based on gov.pl)

As depicted on maps attached (Figure 1), pace of new infections in March in Poland was very dynamic. At the very beginning of period in analysis (March 14), the number of people infected in million citizens did not surpass six in all voivodeships (except Lubuskie voivodeship). Within the following days the pace has been dramatically increasing, and at the end of analysed period rise of infections was noticeable in the majority of Poland's voivodeships (around 31-60 people / million citizens). When analysing the data, it is crucial to pay attention to voivodeships particularly affected by COVID-19 pandemic, namely Masovian, Silesian and Lower Silesian ones. In case of the first, a lot of infections can result from its international impact. This voivodeship (including Poland's capital city) is the biggest region of migrations from abroad, especially of young people (Iglicka, 2001). The most dynamic tourist movement also concentrates there (Kruczala, 1990). Vast number of infections in comparison to the commonalty was also noticeable in Silesian voivodeship. This could have resulted from its central location in the country and labour migrations from neighbouring, having high rate of unemployment, voivodeships (Cudny, 2012). One of the biggest regions with COVID-19 infections is Lower Silesian voivodeship. It can be assumed that the cause of it is its density of population and the fact that this region has a number of mines, which constituted an abode of infections in Poland.

It is essential to mention that the subject of this paper has already been discussed in international literature. Kasare (2020) talks about the impact of COVID-19 pandemic on tourism in India. The author bases the conclusions solely on analysis of information included in newspapers and web pages, and some of the data presented is from previous years. More recent statistics regarding coronavirus' influence on employment in hotel industry are presented by Karim et al. (2020). They claim that this industry in Malesia has found itself in a disastrous situation. Pandemic's impact on tourism in China has been in turn discussed by Hoque et al. (2020). This article, as well as the first one referred to in this paragraph, did not include attempts to analyse the situation based on statistics, but the authors focused on literary sources instead. All of those papers, even if being quite recent, do not contain statistical analysis, which is an added value to this article.

\section{MATERIAL AND METHODS}

The occurring worldwide Coronavirus pandemic (Li, 2020; Fan et al., 2020; Jernigan, 2020; Santosh, 2020) has a negative impact on economy as every epidemic disaster around the world (Appleby-Arnold et al., 2018; Zahnow et al., 2019). This impact is also noticeable in Poland's tourist movement in March 2020. In order to depict changes in this field, data based on established sources (desk research) has been used, taken from, among others, Polish Air Navigation Services Agency (data regarding air traffic) and STR company (analyses of accommodation rate or gastronomy). The data gathered have been compared to data from March last year (that is, March 2019).

The present paper is a critical review on the concurrent developments of tourism and hotel industry in the context of Poland and descriptive elaborations are used with the help of sector statistics. Further, graphical illustrations are used to highlight the emerging trends.

\section{RESULTS AND DISCUSSION}

It can be concluded that in following months COVID-19 will highly impact on global economy and finance especially in air traffic industry, which has also happened in case of H1N1 pandemic in 2009 (Bajardi et al., 2011). This impact will be noticeable in air traffic, which currently serves as a most popular means of transport between countries, especially taking into consideration the fact that far away destinations near Mediterranean Sea (Nowak and Wendt, 2010; Wendt, 2012; Atasoy and Wendt 2016; Wiskulski and Wendt, 2016) are favourite ones of tourists from Poland (Wendt, 2019b). 


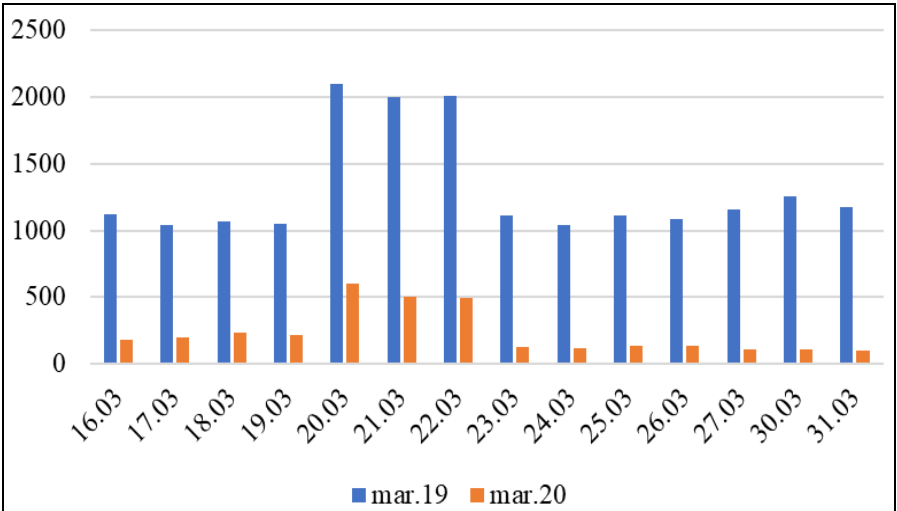

Figure 2. Number of air traffic movement in Polish airspace in March 2019 and march 2020 (Source: own study based on Polish Air Navigation Services Agency)

The end of international flights caused a major decrease in all air traffic in Poland, which can be observed on Figure 2. On the basis of the depicted chart it can be indicated that this decrease is of $80-90 \%$ in comparison to the same period in previous year. Stopping of international and national flights in Poland was a result of this decrease. Air traffic in march 2020 was operated mainly through "LOT do domu" ("Flight home") project aimed in a safe return home of Poles being abroad at that time. Planes for freight transport were used for carriage of masks and other hygiene products. The government's actions in regard to COVID-19 spread in Poland, exacerbated by data provided by WHO (2020), have resulted in temporary closure of accommodation bases in the whole country. Cancellations of different festivals and sport events, suspension of airline movements or closure of important tourist attractions have had a negative impact on global economy (Fernandes, 2020), an important section of which is tourism (Wendt and Bógdał-Brzezińska, 2018). One of the most visible examples of its imbalance is a decrease in accommodation rate, as shown on Figure 3.

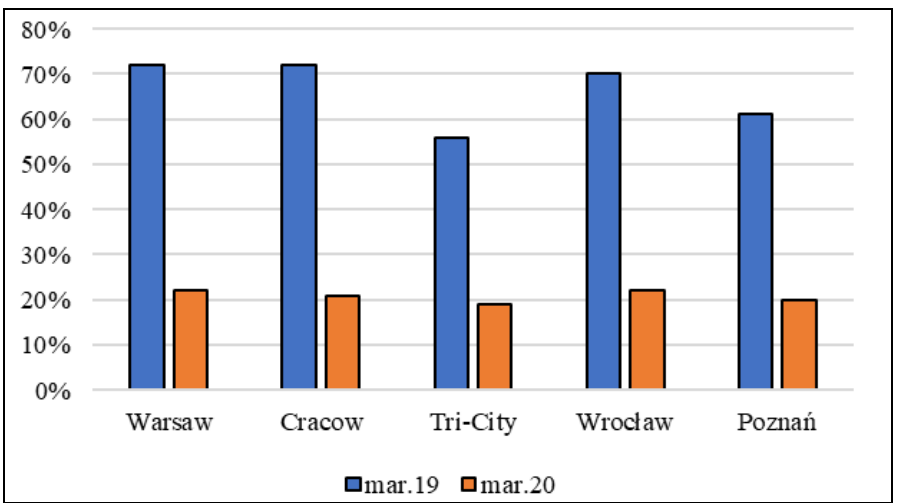

Figure 3. Accommodation rate in chosen cities in March 2019 and 2020 (Source: own study based on STR)

As it can be seen on the chart, accommodation occupancy rate in all Poland's cities fluctuated around 18-22\%. The lowest rate was in Tricity which constituted the only agglomeration with below 20\% rate. The highest one was observable in Warsaw and Wroclaw, which could have resulted from high administrative importance of the first city mentioned. According to STR's data, Polish accommodation occupancy rate has declined in around $70 \%$ in comparison to the previous year, which considerably influenced tourism in the cities in question.

\section{CONCLUSION}

Tourism in Poland in March 2020 was shaped by COVID-19 spread. Great decline in tourist movement was noted, especially in international movement, as a result of few air links available. The accommodation occupancy rate was also significantly lower, as it is strongly correlated to international tourist movements. At the end of March, the government announced closure of all accommodation facilities which resulted in another decline, this time to $0 \%$. Currently (21.05.2020) those are slowly being opened with the observance of hygiene rules. It is essential to note that due to lack of data, only the biggest cities in Poland have been included in the analysis. In the future it will be needed to provide a wider perspective on COVID-19 pandemic's consequences in Poland and conduct a deeper analysis of the country's tourism. The annual contribution of tourism to the Poland economy is 4 to 5 percent and under the COID 19 pandemic the industry performance remained standstill. The drop of the hotel occupancy percentage clearly indicates the potential economic impact over tourism industry and consequently on the Poland economy. Though it's too early to jump into hasty conclusions on the overall impacts of Corona outbreak the global repercussions over the Poland economy would be invertible. Novel SOPs, regulations and procedures to function under new normal conditions are necessary for tourism industry to move forward both locally and globally.

\section{REFERENCES}

Abu Bakar, N., \& Rosbi, S., (2020). Effect of Coronavirus disease (COVID-19) to tourism industry. International Journal of Advanced Engineering Research and Science, 7(4), 189-193. https://dx.doi.org/10.22161/ijaers.74.23

Appleby-Arnold, S., Brockdorff, N., Jakovljev, I., \& Zdravković, S. (2018). Applying cultural values to encourage disaster preparedness: Lessons from a lowhazard country. International Journal of Disaster Risk Reduction, 31, 37-44. https://doi.org/10.1016/j.ijdrr.2018.04.015

Atasoy, E., \& Wendt, J.A. (2016). Changes in tourist traffic from Poland to Turkey on the background of other major directions of travel. Journal of Geography, Politics and Society, 6(4), 39-44. http://dx.doi.org/10.4467/24512249JG.16.026.5813

Bajardi, P., Poletto, C., Ramasco, J.J., Tizzoni, M., Colizza, V., \& Vespignani, A. (2011). Human mobility networks, travel restrictions, and the global spread of 2009 H1N1 pandemic. PloS one, 6(1). https://doi.org/10.1371/journal.pone.0016591 
Carlos, W.G., Dela Cruz, C.S., Cao, B., Pasnick, S., \& Jamil, S. (2020). Novel Wuhan (2019-nCoV) coronavirus. American journal of respiratory and critical care medicine, 201(4), 7-8. https://doi.org/10.1164/rccm.2014P7

Cascella, M., Rajnik, M., Cuomo, A., Dulebohn, S.C., \& Di Napoli, R. (2020). Features, evaluation and treatment coronavirus (COVID-19). In Statpearls [internet]. StatPearls Publishing. http://www.ncbi.nlm.nih.gov/books/nbk554776/

Cudny, W. (2012). Socio-Economic Changes in Lodz-Results of Twenty Years of System Transformation. Geografický časopis, 64(1), 3-27.

Fan, C., Liu, L., Guo, W., Yang, A., Jilili, M., Ren, M., Xu, P., Long, H., \& Wang, Y. 10 (2020). Prediction of epidemic spread of the 2019 novel coronavirus driven by spring 11 festival transportation in China: A population-based study. International Journal of 12 Environmental Research and Public Health, 17(5), 1-27. https://doi.org/10.3390/ijerph17051679

Fernandes, N. (2020). Economic effects of coronavirus outbreak (COVID-19) on the world economy. Available at SSRN 3557504. DOI:10.12691/jfe-8-2-5

Hoque, A., Shikha, F.A., Hasanat, M.W., Arif, I., \& Hamid, A.B.A. (2020). The Effect of Coronavirus (COVID-19) in the Tourism Industry in China. Asian Journal of Multidisciplinary Studies, 3(1), 52-58.

Iglicka, K. (2001). Migration Movements from and into Poland in the Light of East-West European Migration. International Migration, 39(1), 3-32. https://doi.org/10.1111/1468-2435.00133

IIies, D. C., Onet, A., Wendt, J. A., Ilieș, M., Timar, A., Ilies, A., ... \& Herman, G. V. (2018). Study on microbial and fungal contamination of air and wooden surfaces inside of a historical Church from Romania. Journal of Environmental Biology, 39(6), 980-984.

Jernigan, D.B. (2020). Update: Public Health Response to the Coronavirus Disease 201932 Outbreak - United States, February 24, 2020, MMWR. Morbidity and mortality weekly 33 report 69(8), 216-219. http://dx.doi.org/10.15585/mmwr.mm6908e1

Karim, W., Haque, A., Anis, Z., \& Ulfy, M.A. (2020). The Movement Control Order (MCO) for COVID-19 Crisis and its Impact on Tourism and Hospitality Sector in Malaysia. International Tourism and Hopitality Yournal, 3(2), 1-07. https://doi.org/10.37227/ithj-2020-02-09

Kasare, K.S. (2020). Effects of Coronavirus Disease (COVID-19) on Tourism Industry of India. Studies in Indian Place Names, $40(35)$, 362-365.

Kruczala, J. (1990). Tourism planning in Poland. Annals of Tourism Research, 17(1), 69-78. https://doi.org/10.1016/0160-7383(90)90115-8

Li, G. (2020). The Challenges and Responsibilities of Family Doctors in the New Global Coronavirus Outbreak. Chinese General Practice, 23(7), 761-762. https://dx.doi.org/10.1136\%2Ffmch-2020-000333

Nowak, M., \& Wendt, J., (2010). Hurghada as one of the major destination of Polish tourism, in: Wendt J., (eds.), Chosen problems of geographical research in Poland and Romania, Editura University of Oradea, Oradea, 99-109.

Ranasinghe, R. (2020). Post-COVID19 (Novel Corona) Economic Recovery: Critical Review on Economic Immunity of Sri Lanka. Available at SSRN 3587179.

Ranasinghe, R., \& Cheng, L. (2020). Tourism-Driven Mobilities: Scale Development Approach in Postwar Growth Setting in Sri Lanka. International Journal of Asian Business and Information Management, (IJABIM), 11(3), 119-134.

Santosh, K.C. (2020). AI-Driven Tools for Coronavirus Outbreak: Need of Active 18 Learning and Cross-Population Train/Test Models on Multitudinal/Multimodal Data. 19, Journal of Medical Systems, 44(5), 1-5. https://doi.org/10.1007/s10916-020-01562-1.

Sohrabi, C., Alsafi, Z., O’Neill, N., Khan, M., Kerwan, A., Al-Jabir, A., Losifidis, Ch., Agha, R. (2020). World Health Organization declares global emergency: A review of the 2019 novel coronavirus (COVID-19). International Journal of Surgery, 76, 71-76. https://doi.org/10.1016/j.ijsu.2020.02.034

Wahyuningtyas, N., Tanjung, A., Idris, I. \& Islam, M.N. (2020). Accelerating tourism development by community preparedness on disaster risk in Lombok, Indonesia. GeoJournal of Tourism and Geosites, 29(2), 545-553. https://doi.org/10.30892/gtg.29213-488

Wendt, J.A. (2012). Changes of Polish tourist flows to the Eastern Adriatic, in: P. Jordan (ed.), Regional development and regionalisation in the Adriatic space. ISR-Forschungsberichte, 38, 159-165.

Wendt, J.A. (2016). Zmiany w turystycznym transporcie lotniczym Egiptu w latach 2005-2014 [Changes in the Tourist Air Transport in Egypt in 2005-2014]. Prace Komisji Geografii Komunikacji Polskiego Towarzystwa Geograficznego, 4(30), 92-101 (in Polish). https://doi.org/10.24917/3327

Wendt, J.A. (2018). Nowa turystyka w świecie ponowoczesnym - próba budowy definicji [New tourism in the postmodern world - an attempt to construction the definition] in: Olszewski-Strzyżowski D.J., Dróżdż R., Pasek M., (eds.), Turystyka. Nowe Trendy, Zeszyty Naukowe, 6, 37-59 (in Polish).

Wendt, J.A. (2019). Geographical diversity and changes in foreign trips from Poland in 2009-2018. Bulletin of L.N. Gumilyov Eurasian National University, Chemistry. Geography. Ecology Series, 3(128), 125-135. http://dx.doi.org/10.32523/2616-6771-2019-128-3-126-134

Wendt, J.A. (2020). New tourism in XXI century - new definition. Актуальные проблемы науки и образования в области естественных и сельскохозяйственных наук: материалы международной научно-практической конференции, Петропавловск: СКГУ им. М. Козыбаева. [Асtuа problems of science and education in the field of natural and agricultural sciences: materials of the international scientific-practical conference, Petropavlovsk: NKSU named after M. Kozybaeva], T. 2, 94-98.

Wendt, J.A., \& Bógdał-Brzezińska, A. (2018). Problematyka, metody i problemy badań w geografii turystycznej [Problematics, methods and problems of tests in tourist geography], in: Olszewski-Strzyżowski D.J., Dróżdż R., Pasek M., (red.), Turystyka. Nowe Trendy, Zeszyty Naukowe, 7, 7-42 (in Polish).

Wendt, J.A. (2019). Comparison of the impact of the Arab Spring and terrorist attacks on the decline in tourism in Egypt and Tunisia (2010-2015). GeoJournal of Tourism and Geosites, 27(4), 1367-1376. https://doi.org/10.30892/gtg.27421-440

Wiskulski, T., \& Wendt, J.A. (2016). Dostępność komunikacyjna z Polski regionów turystycznych wybrzeża Chorwacji [Transport Accessibility from Poland to Tourist Regions of the Croatian Coastline]. Prace Komisji Geografii Komunikacji Polskiego Towarzystwa Geograficznego, 4(30), 79-91 (in Polish). https://doi.org/10.24917/3326

Zahnow, R., Wickes, R., Taylor, M., \& Corcoran, J. (2019). Community social capital and individual functioning in the post-disaster context. Disasters, 43(2), 261-288. https://doi.org/10.1111/disa.12317

*** World Health Organization. (2020). Critical preparedness, readiness and response actions for COVID-19: interim guidance, 22 March 2020 (No. WHO/2019 nCoV/Community Actions/ 2020.3). World Health Organization.

https://www.adb.org/news/covid-19-economic-impact-could-reach-8-8-trillion-globally-new-adb-report Asian Development Bank, Updated Assessment of the Potential Economic Impact of COVID-19, Date of appeal: May 2020.

https://www.gov.pl/, The website of the Republic of Poland, Date of appeal: May 2020 (in Polish).

https://www.wprost.pl/kraj/10304919/koronawirus-w-polsce-minister-zdrowia-jest-kolejny-przypadek-choroby.html, Wprost Magazine, Date of appeal: May 2020 (in Polish). 